\title{
Diversity of Macrophomina phaseolina (Tassi) Goid Based on Chlorate Phenotypes and Pathogenicity
}

\author{
Siavosh Rayatpanah (Corresponding author) \& Seyed Alireza Dalili \\ Department of Plant Protection \\ Agricultural and Natural Resources Research Center of Mazandaran \\ PO box 48175-556, Sari, Iran \\ Tel: 98-911-126-4529 E-mail: rayat_s_ag@yahoo.com
}

Esmaeil Yasari

Agriculture Department, Payame Noor University, 19395-4697, Tehran, Iran

Received: October 8, $2011 \quad$ Accepted: October 21, $2011 \quad$ Published: April 1, 2012

doi:10.5539/ijb.v4n2p54

URL: http://dx.doi.org/10.5539/ijb.v4n2p54

\begin{abstract}
Macrophomina phaseolina (Tassi) Goid causes charcoal disease of oilseed plants. In this study 24 isolates, which were obtained from sunflower, soybean and sesame, were compared based on chlorate phenotypes and pathogenicity tests. For chlorate phenotypes, the isolates were grown on potassium chlorate and stored at $30^{\circ} \mathrm{C}$ in darkness. For pathogenicity test, seeds of sunflower, soybean and maize plants were placed on 6 - day - old colonies of each Macrophomina isolates grown on PDA and kept at $30^{\circ} \mathrm{C}$ in the dark. Results indicate that the sesame isolates had more colony radius rate on chlorate minimal medium in comparison to the soybean and sunflower isolates. The sesame isolates were chlorate resistant and grew normally with numerous dark microsclerotia production on the potassium chlorate. The soybean and sunflower isolates were chlorate sensitive and divided into two classes. Class 1, include the isolates that grew sparsely with a feathery like pattern, and the other one had a completely restricted radial growth meaning that $M$. phaseolina isolates differed in their ability to use certain nitrogenous compounds. Analysis of variance showed a significant difference between the colony radius rates of the isolates at 1\% probability level. Based on Duncan's test, the isolates have been divided in 14 classes. Results of pathogenicity test showed that there was significant difference $(\mathrm{P}<0.01)$ between the isolates. The results confirmed that the feathery like pattern of the isolates was more virulent on soybean and sunflower.
\end{abstract}

Keywords: Macrophomina phaseolina, Chlorate phenotype, Pathogenicity test, Oilseed plants

\section{Introduction}

Macrophomina phaseolina (Tassi) Goid, is an anamorphic and soil borne fungus with a broad host range that includes 75 plant families and more than 500 species worldwide (Salik, 2007). Many economically significant plants including legumes, vegetables, fruits and fiber crops are attacked by M. phaseolina, a causal agent of charcoal rot disease (Kunwar and Sin, 1986; Sinclair and Backman, 1986; Smith and Carvil, 1997). Estimates of yield reduction due to charcoal rot in the US were 1.98, 0.28, and 0.49 million metric tons in 2003, 2004, and 2005, respectively (Wrather and Koenning, 2006). Macrophomina phaseolina is the most fungal pathogens affecting sunflower in Egypt (Purkayastha et al., 2006). Despite having a wide host range, Macrophomina is a monotypic genus. Efforts to divide $M$. phaseolina into sub-species were unsuccessful, based on the morphology and pathogenicty, there were extremely intraspecified variations (Dhingra and Sinclair, 1972; Echavez-Badel and Perdomo, 1991). The significant differences of morphological (Mayek-Perez et al., 2001), physiological (Mihali and Taylor, 1995), pathogenic (Mayek-Perez et al., 2001; Su et al., 2001) and genetic (Vandemark et al., 2000; Mayek-Perez et al., 2001; Su et al., 2001; Alvaro et al., 2003; Jana et al., 2003; Aboshosha et al., 2007) diversity have been reported. Control has not yet been achieved through resistance in spite of reports on tolerant genotypes (Smith and Carvil, 1997). Chlorate phenotypes were used as markers for identifying host-specific isolates of $M$. phaseolina (Das et al., 2006). Many researchers have also found great variability in pathogenicity and morphology among isolates from the same host. It is assumed that during the hyphal fusion, heterokaryosis could occur after 
mitotic segregation and recombination (Sinclair and Backman, 1986). This may explain the occurrence of cultural types or physiological races of M. phaseolina (Dhingra and Sinclair, 1973; Manici et al., 1995). Recent efforts to classify isolates of M. phaseolina have centered on morphology of the colony on media amended with chlorate (Su et al., 2001). Most fungi can use nitrate as a source of nitrogen. Nitrate uptake does not appear to occur without nitrate metabolism. The metabolic assimilation of nitrate is by reduction to nitrite via nitrate reductase, nitrite is then reduced to ammonia. Chlorite could restrict the growth when the nitrate reductase pathway is active. Unrestricted growth in the sectors resulted from the inactivity of one or more of the five enzymes in the nitrate reductase pathway (Cloud and Rupe, 1988; Mccain and Smith, 1972; Solomonson and Vennesland, 1972). Nitrate reductase also can reduce chlorate to chlorite. The accumulation of chlorite is presumably poisonous to cells. Fungal strains that have functional nitrate reductase are chlorate sensitive, whereas those that are unable to catabolize nitrate are chlorate resistant (Pearson and Leslie, 1987). In this study we have attempted to separate and classify the isolates of $M$. phaseolina obtained from the oilseed plants on the basis of pathogenicity test, morphology and growth manner on minimal medium containing chlorate.

\section{Materials and Methods}

\subsection{Fungal isolates}

Twenty-four samples were collected from infected stems and roots of soybean, sunflower and sesame plants from Mazandaran Province in northern Iran (Table 1). Each root or stem was thoroughly washed and dried at room temperature. Four small $0.3 \mathrm{~cm}$ epidermal sections were excised from each sample and sterilized in $0.8 \% \mathrm{NaOCl}$ ( $1 \mathrm{~min}$ ) and washed in sterile water for $1 \mathrm{~min}$. Tissues were placed on potato dextrose agar (PDA) plate followed by incubation at $28 \pm 1^{\circ} \mathrm{C}$ in darkness for four days. Purification was developed by single microesclerotium culture and maintained on PDA at $28 \pm 1^{\circ} \mathrm{C}$ (Das, and Fakrudin, 2006). All 24 isolates employed in the present investigation are listed in Table 1.

\subsection{Phenotypic study}

A $1 \mathrm{~mm}$ agar plug from the 7 day-old pure culture was placed on minimal medium containing potassium chlorate with some modification (20g agar, $1.6 \mathrm{~g}$ asparagine, $15 \mathrm{~g}$ potassium chlorate, $30 \mathrm{~g}$ sucrose, $2 \mathrm{~g} \mathrm{NaNO}, 1 \mathrm{~g} \mathrm{KH}_{2} \mathrm{PO}_{4}$, $0.5 \mathrm{~g} \mathrm{MgSO}_{4} \cdot 7 \mathrm{H}_{2} \mathrm{O}$ and the final reaction volume was adjusted to $1000 \mathrm{ml}$ with $\mathrm{H}_{2} \mathrm{O}$ ) and $0.2 \mathrm{ml}$ of trace elements solutions (95ml distilled water, $10 \mathrm{~g}$ citric acid, $10 \mathrm{~g} \mathrm{ZnSO}_{4} \cdot 7 \mathrm{H}_{2} \mathrm{O}, 2 \mathrm{~g} \mathrm{Fe}\left(\mathrm{NH}_{4}\right)_{2}\left(\mathrm{SO}_{4}\right)_{2} \cdot 6 \mathrm{H}_{2} \mathrm{O}, 0.5 \mathrm{~g} \mathrm{CuSO}_{4} \cdot 5 \mathrm{H}_{2} \mathrm{O}$, $100 \mathrm{mg} \mathrm{MnSO}_{4} \cdot \mathrm{H}_{2} \mathrm{O}, 100 \mathrm{mg} \mathrm{H}_{3} \mathrm{BO}_{3}, 100 \mathrm{mg} \mathrm{Na}_{2} \mathrm{MoO}_{4} \cdot 2 \mathrm{H}_{2} \mathrm{O}$ and $1 \mathrm{ml}$ chloroform) was added and kept at $30^{\circ} \mathrm{C}$ in darkness. The $\mathrm{pH}$ of the minimal medium was adjusted to 6.5 with $\mathrm{KOH}$ before autoclaving (Puhalla and Spieth, 1985). The colony radius rates of the isolates were evaluated by factorial experiment based on completely randomized design (CRD) in four replications. After 48 hours, the colony radius was measured daily with ruler. The minimal medium without potassium chlorate was used as a control treatment.

\subsection{Pathogenicity test}

In this experiment pathogenicity test of isolates was carried out at the seedling stage of soybean (Glycine max L.), sunflower (Helianthus annuus L.) and maize (Zea mays L.) plants in a completely randomized block design. Each treatment (isolate) was replicated three times and included two plates with six seeds per plate. Seeds of the plants were sterilized with $2 \%$ sodium hypochlorite for $4 \mathrm{~min}$ and rinsed twice in sterile water. Seeds were placed on 6-day-old colonies of the Macrophomina isolate (on PDA plates) and incubated at $30^{\circ} \mathrm{C}$ in dark condition. Evaluation was done after six days, using the following severity assessment key: $0=$ healthy seed; $1=$ discoloration of a portion of the seedling in contact with the mycelium; 2 = seed teguments invaded by mycelium and sclerotia but healthy seedling; 3 = seed teguments free from the fungus but seedling infected; $4=$ seed tegument and seedling infected; $5=$ seed infected and not germinated (Manici et al., 1992).

The disease index was calculated by multiplying the number of seeds by the degree of disease severity. The experimental design was a randomized complete. Analysis of variance (ANOVA) of the data was performed with the MSTAT-C package.

\section{Results and Discussion}

\subsection{Phenotypic study}

Three various growth patterns (feathery spreading growth, restricted growth and dense growth) were observed, when the isolates were grown on the minimal medium containing $120 \mathrm{mM}$ potassium chlorate (Table 2, Figure 1).

Restricted and feathery isolates were sensitive to chlorate, whereas dense isolates were resistant to chlorate. Among soybean isolates, feathery isolates were much more abundant than restricted, whereas dense isolates predominated in sesame. Sclerotia production on chlorate medium by the sensitive isolates was too low compared 
to resistant ones. Isolates of sesame grew more rapidly on the defined medium containing chlorate than did isolates from soybean or sunflower.

All isolates had dense growth when they were grown on the minimal medium without chlorate and could not be differentiated. The growth response of isolates did not alter by increasing chlorate concentrations from 120 to 240 $\mathrm{mM}$, whereas dense and feathery growth appeared similar in the lower concentration $(60 \mathrm{mM})$.

Su et al. (2001) and Pearson et al. (1986) reported that mycelial growth of M. phaseolina on chlorate medium was classified into three categories (restricted, feathery and dense). Restricted and feathery isolates were sensitive to chlorate, whereas dense isolates were resistant to chlorate. Manici et al. (1995) reported that four colony chlorate phenotypes were observed.

Analysis of variance of the data showed that the colony radius rate of 24 isolates of Macrophomina phaseolina was significantly different $(\mathrm{P}<0.01)$ on chlorate minimal medium (Table 3$)$.

Different colony radius rates were observed in M. phaseolina isolates on chlorate minimal media. Based on Duncan's test, comparison of the means of colony radius rates grouped the 24 isolates in 14 classes on chlorate minimal media (Table 4). Isolate 4 and 7 on chlorate minimal medium had the highest colony radius rate. The chlorate resistant isolates had more radius rates than those in chlorate minimal medium. The results were similar to the reported by Manici (Manici et al., 1992) (Table 4).

\subsection{Pathogenicity test}

The experiment of the pathogenicity test demonstrated that none of the isolates were pathogenic on maize while all isolates showed pathogenic ability on soybean and sunflower (Figure 2).

Analysis of variance showed that the pathogenicity of the 24 isolates of $M$. phaseolina was significantly different $(\mathrm{P}<0.01)$ on the plant species (Table 5).

Disease indices on sunflower and soybean range between 19 - 24 and 27- 30 respectively. The means comparison of the different isolates indicate that there was significant difference among isolates on the rate of the disease index. Isolate 2, 5, 11, 23 and 24 indicate maximum disease index (27.00) and were placed in class A, while isolates 10 showed minimum disease index (23.17) and were grouped in class K (Table 6). Femandez et al., (2006) reported that great variability in pathogenicity was recognized among isolates from different host species and between isolates (Femandez et al., 2006). Das et al., (2006) was investigated pathogenicity of some isolates of $M$. phaseolina that belong to different country. The results showed the pathogenicity of isolates was different and the most aggressive isolates were from Mexico, Brezil and Colombia (Das et al., 2006).

(Table 6)

Means comparison of different plants species reaction showed that there was significant difference $(\mathrm{P}<0.01)$ on the rate of disease index, hence, the plant species were placed in different groups (Table 7). Soybean with 28.56 had more level of sensitivity (class A) than sunflower (class B) with 22.48 .

(Table 7)

Mean comparison of interaction between host plants and isolates showed significant difference $(\mathrm{P}<0.01)$. All of isolates were pathogenic on soybean and sunflower. Isolates $24,5,11$ and 23 showed most intensity on both soybean and sunflower, and the intensity of all isolates was more on soybean than on sunflower (Table 8).

The pathogenicity test showed that soybean and sunflower plants are susceptible while maize plant is resistant to Macrophomina. All the 24 isolates that were tested for charcoal rot reaction could infect soybean and sunflower. A broad pathogenic and phenotypic diversity was noticed among Iranian M. phaseolina.

Mayek-Prez et al. (2001) studied 84 isolates of M. phaseolina from different geographical regions of Mexico, and identified 43 distinct pathotypes. Su et al. (2001) found high levels of variation in pathogenecity of M. phaseolina. Manici (1995) investigated pathogenecity of M. phaseolina on eight plant species, and all were pathogenic on other plant species except on maize. Isolates were highly virulent on soybean and virulent on sunflower, safflower, sorghum and melon. Studies on M. phaseolina have investigated variations in morphology and pathogenicity among isolates from soybean, common bean and cluster bean (Purkayastha et al., 2006).

In our study the most aggressive isolates originated from North of Mazadaran province were mainly isolated from soybean plants. The study also demonstrated that some chlorate sensitivity in M. phaseolina had some relation with charcoal rot severity in soybean and sunflower. Similar results were reported by Mihali and Taylor (1995) and Mayek-Perez et al. (2001). 


\section{References}

Aboshosha, S. S., Attaalla, S. I., EL-Korany, A. E., \& El-Argawy, E. (2007). Characterization of Macrophomina phaseolina isolates affecting sunflower growth in El-Behera governorate, Egypt. International Journal of Agriculture and Biology, 6. $807-815$.

Alvaro, M. R. A., Ricardo, V. A., Carlos, A. A. A., Valdemar, P. C., David S. J. F., Silvana, R. R. M., Luis, C. B., Mauro, C. P., \& Claudio, G. P. C. ( 2003). Genotypic diversity among Brazilian isolates of Macrophomina phaseolina revealed by RAPD. Fitopatologia Brasileira, 28, $279 \quad-\quad 285$. http://dx.doi.org/10.1590/S0100-41582003000300009

Cloud, G. L., \& Rupe, J. C. (1988). Preferential host selection of isolates of Macrophomina phaseolina. Phytopathology, 78, 1563.

Das, L. R., Fakrudin, B., \& Arora, D. K. (2006). RAPD cluster analysis and chlorate sensitivity of some Indian isolates of Macrophomina phaseolina from sorghum and their relationships with pathogenicity. Microbiological Research, 3, 646 - 649 .

Dhingra, O. D., \& Sinclair, J. B. (1972). Variation among isolates of Macrophomina phaseolina (Rhizoctonia bataticola) from the same soybean plant. Phytopathology, 62, 511- 518.

Dhingra, O. D., \& Sinclair, J. B. (1973). Variation among isolates of Macrophomina phaseolina from different regions. Phytopathology, 76, $2000-2004$.

Echavez-Badel, R., \& Perdomo, A. (1991). Characterization and comparative pathogenicity of two Macrophomina phaseolina isolates from Puerto Rico. J. Agric. Univ. P. R., 75, 419-421.

Femandez, R. B. A., Santiago, D. E., Delgado, S. H., \& Perez, N. M. (2006). Characterization of Mexican and non- Mexican isolates of Macrophomina phaseolina based on morphological characteristics, pathogenicity on bean seeds and endoglucanase gene. J. Pl. Path, 88, 1.

Jana, T, Sharma, T. R., Prasad, R. D., \& Arora, D. K. (2003). Molecular characterization of Macrophomina phaseolina and Fusarium species by a single primer RAPD technique. Microbiological Research, 158, $249-$ 257. http://dx.doi.org/10.1078/0944-5013-00198

Kunwar, I. R., Sinyh, T., Machado, C. C., \& Sinclair, J. B. (1986). Histopathology of soybean seed and seedling infection by Macrophomina phaseolina. Phytopathology, 76, 532 - 535. http://dx.doi.org/10.1094/Phyto-76-532

Manici, L. M., Caputo, F., \& Cerato, C. (1995). Temperature responses of isolates of Macrophomina phaseolina from different climatic regions of sunflower production in Italy. Plant Disease, 79, $834-838$. http://dx.doi.org/10.1094/PD-79-0834

Manici, L. M., Cerato, C., \& Caputo, F. (1992). Pathogenic and biological variability of Macrophomina phaseolina (Tassi) Goid. isolates in different areas of sunflower cultivation in Italy. 13th Proc. of Intern. Sunflower Conf, 1, $779-784$.

Mayek-Perez, N., Lopez-Castaneda, C., Gonzalez-Chavira M., Garcia-Espinosa R., Acosta-Gallegos J. A., Martinez, D. I., Vega, O., \& Simpson, J. (2001). Variability of Mexican isolates of Macrophomina phaseolina, based on the pathogenesis and AFLP genotype. Physiological and Molecular Plant Pathology, 59, 257 - 263. http://dx.doi.org/10.1006/pmpp.2001.0361

Mccain, A. H., \& Smith, R. S. (1972). Quantitative assay of Macrophomina phaseolina from soil. Phytopathology, 62, 1098. http://dx.doi.org/10.1094/Phyto-62-1098

Mihali, J. D., \& Taylor, S. J. (1995). Interpreting variability among isolates of Macrophomina phaseolina in pathogenicity, pycnidium production and chlorate utilization. Canadian Journal of Botany, 73, 1596-1603. http://dx.doi.org/10.1139/b95-172

Pearson, C. A. S, Leslie, J. F., \& Schwenk, F. W. (1986). Variable chlorate resistance in Macrophomina phaseolina from corn, soybean and soil. Phytopathology, 76, 646 - 649. http://dx.doi.org/10.1094/Phyto-76-646

Pearson, C. A. S., Leslie, J. F., \& Schwenk, F. W. (1987). Host preference correlated with chlorate resistance in Macrophomina phaseolina. Plant Disease, 71, 828 - 831. http://dx.doi.org/10.1094/PD-71-0828

Puhalla, J. E., Spieth, P. T. A. (1985). Comparison of heterokaryosis and vegetative incompatibility among varieties of Gibberella fujikuroi (Fusarium moniliforme). Exp. Mycology, 9, $39 \quad-\quad 47$. http://dx.doi.org/10.1016/0147-5975(85)90045-3 
Purkayastha, S., Kaur, B., Dilbaghi, N., \& Chaudthury, A. (2006). Characterization of Macrophomina phaseolina, the charcoal rot pathogen of cluster bean, using conventional techniques and PCR-RAPD based molecular markers. Plant pathology, 55, 106 - 116. http://dx.doi.org/10.1111/j.1365-3059.2005.01317.x

Salik, N. K. (2007). Macrophomina phaseolina as causal agent for Charcoal rot of sunflower. 2, $111-118$.

Sinclair, J. B., \& Backman, P. A. (1986). Compendium of soybean diseases. Third edition The American Phytopathological Society, $30-33$.

Smith, G. S., \& Carvil, O. N. (1997). Field screening of commercial and experimental soybean cultivars for their reaction to Macrophomina phaseolina. Plant $\quad$ Disease, $\quad 81, \quad 363 \quad-\quad 368$. http://dx.doi.org/10.1094/PDIS.1997.81.4.363

Solomonson, L. P., \& Vennesland, B. (1972). Nitrate reductase and chlorate toxicity in Chlorella vulgaris Berjeerinck. Plant Physiology, 50, 421 - 423. http://dx.doi.org/10.1104/pp.50.4.421

Su, G., Suh, S. O., Schneider, R. W., \& Russin, J. S. (2001). Host specialization in the charcoal rot fungus Macrophomina phaseolina. Phytopathology, 91, 120 - 126. http://dx.doi.org/10.1094/PHYTO.2001.91.2.120

Vandemark, G., Martinez, O., Pecina, V., \& Alvarado, M. J. (2000). Assessment of genetic relationships among isolates of Macrophomina phaseolina, using a simplified AFLP technique and two different methods of analyses. Mycologia, 92, 656 - 664. http://dx.doi.org/10.2307/3761423

Wrather, J. A., \& Koenning, S. R. (2006). Estimates of disease effects on soybean yields in the United States 2003-2005. Journal Nematol, 38, $173-180$.

Table 1. Macrophomina phaseolina isolates characteristics, used in this study

\begin{tabular}{|c|c|c|}
\hline No. of Isolates & Hosts & Geographic origin \\
\hline 1 & Soybean & Ghamemshar \\
\hline 2 & Soybean & Behshar \\
\hline 3 & Sunflower & Neka \\
\hline 4 & Sesame & Behshar \\
\hline 5 & Soybean & Behshar \\
\hline 6 & Soybean & Ghamemshar \\
\hline 7 & Sesame & Neka \\
\hline 8 & Soybean & Galoga \\
\hline 9 & Soybean & Goybar \\
\hline 10 & Sesame & Galoga \\
\hline 11 & Soybean & Galoga \\
\hline 12 & Soybean & Goybar \\
\hline 13 & Soybean & Sari \\
\hline 14 & Soybean & Sari \\
\hline 15 & Soybean & Galoga \\
\hline 16 & Soybean & Goybar \\
\hline 17 & Soybean & Ghamemshar \\
\hline 18 & Soybean & Sari \\
\hline 19 & Soybean & Sari \\
\hline 20 & Soybean & Sari \\
\hline 21 & Soybean & Neka \\
\hline 22 & Soybean & Neka \\
\hline 23 & Soybean & Galoga \\
\hline 24 & Soybean & Behshar \\
\hline
\end{tabular}


Table 2. Chlorate phenotypes of Macrophomina phaseolina isolates obtained from different hosts

\begin{tabular}{|c|c|c|c|c|}
\hline No. of isolates & Source & Collection site & $\begin{array}{l}\text { Chlorate } \\
\text { reaction }\end{array}$ & Phenotype \\
\hline 5 & Soybean & Behshar & Sensitive & Feathery \\
\hline 2 & Soybean & Behshar & Sensitive & Feathery \\
\hline 24 & Soybean & Behshar & Sensitive & Feathery \\
\hline 11 & Soybean & Galoga & Sensitive & Feathery \\
\hline 23 & Soybean & Galoga & Sensitive & Feathery \\
\hline 15 & Soybean & Galoga & Sensitive & Feathery \\
\hline 8 & Soybean & Galoga & Sensitive & Restricted \\
\hline 1 & Soybean & Ghamemshar & Sensitive & Feathery \\
\hline 6 & Soybean & Ghamemshar & Sensitive & Feathery \\
\hline 17 & Soybean & Ghamemshar & Sensitive & Feathery \\
\hline 12 & Soybean & Goybar & Sensitive & Feathery \\
\hline 9 & Soybean & Goybar & Sensitive & Feathery \\
\hline 16 & Soybean & Goybar & Sensitive & Feathery \\
\hline 22 & Soybean & Neka & Sensitive & Feathery \\
\hline 21 & Soybean & Neka & Sensitive & Feathery \\
\hline 18 & Soybean & Sari & Sensitive & Feathery \\
\hline 19 & Soybean & Sari & Sensitive & Feathery \\
\hline 13 & Soybean & Sari & Sensitive & Feathery \\
\hline 20 & Soybean & Sari & Sensitive & Feathery \\
\hline 14 & Soybean & Sari & Sensitive & Feathery \\
\hline 3 & Sunflower & Neka & Sensitive & Feathery \\
\hline 4 & Sesame & Behshar & Resistant & Dense \\
\hline 10 & Sesame & Galoga & Sensitive & Feathery \\
\hline 7 & Sesame & Neka & Resistant & Dense \\
\hline
\end{tabular}

Table 3. Analysis of variance colony radius rate of 24 isolates of M. phaseolina

\begin{tabular}{|c|l|l|l|l|l|l|}
\hline $\begin{array}{c}\text { K } \\
\text { Value }\end{array}$ & Source & $\begin{array}{l}\text { Degrees of } \\
\text { Freedom }\end{array}$ & $\begin{array}{l}\text { Sum of } \\
\text { Square }\end{array}$ & $\begin{array}{l}\text { Mean of } \\
\text { Square }\end{array}$ & F Value & Prob \\
\hline 2 & Replication & 2 & 66.778 & 33.389 & 5418.9271 & 0.0000 \\
\hline 4 & Treatment & 23 & 199.075 & 8.655 & 1404.7420 & 0.0000 \\
\hline 6 & $\begin{array}{l}\text { Replication* } \\
\text { Treatment }\end{array}$ & 46 & 15.417 & 0.335 & 54.3956 & 0.0040 \\
\hline 7 & Error & 216 & 1.331 & 0.006 & & \\
\hline & Total & 287 & 282.601 & & & \\
\hline
\end{tabular}

Coefficient of Variation: $4.52 \%$. 
Table 4. The mean comparison of 24 isolates based on Duncan's test for colony radius rate at minimal medium

\begin{tabular}{|c|c|c|c|}
\hline Isolates code & Source & Means & class \\
\hline 4 & Sesame & 3.150 & A \\
\hline 7 & Sesame & 3.141 & $\mathrm{~A}$ \\
\hline 1 & Soybean & 3.096 & $\mathrm{~A}$ \\
\hline 10 & Sesame & 2.950 & B \\
\hline 5 & Soybean & 2.633 & $\mathrm{C}$ \\
\hline 17 & Soybean & 2.534 & $\mathrm{D}$ \\
\hline 22 & Soybean & 2.400 & $\mathrm{E}$ \\
\hline 6 & Soybean & 2.162 & $\bar{F}$ \\
\hline 16 & Soybean & 2.033 & G \\
\hline 3 & Sunflower & 1.967 & $\mathrm{G}$ \\
\hline 18 & Soybean & 1.702 & $\mathrm{H}$ \\
\hline 19 & Soybean & 1.533 & I \\
\hline 23 & Soybean & 1.500 & I \\
\hline 24 & Soybean & 1.299 & $\mathrm{~J}$ \\
\hline 15 & Soybean & 1.267 & $\mathrm{~J}$ \\
\hline 20 & Soybean & 1.182 & K \\
\hline 13 & Soybean & 1.048 & $\mathrm{~L}$ \\
\hline 2 & Soybean & 1.034 & $\mathrm{~L}$ \\
\hline 12 & Soybean & 1.033 & $\mathrm{~L}$ \\
\hline 14 & Soybean & 1.033 & $\mathrm{~L}$ \\
\hline 21 & Soybean & 1.023 & $\mathrm{~L}$ \\
\hline 11 & Soybean & 0.998 & $\mathrm{~L}$ \\
\hline 9 & Soybean & 0.733 & $\mathrm{M}$ \\
\hline 8 & Soybean & 0.233 & $\mathrm{~N}$ \\
\hline
\end{tabular}

Table 5. Analysis of variance pathogenicity test of M. phaseolina on the two plant species

\begin{tabular}{|l|l|l|l|l|l|l|}
\hline K Value & Source & $\begin{array}{l}\text { Degrees of } \\
\text { Freedom }\end{array}$ & Sum of Square & $\begin{array}{l}\text { Mean of } \\
\text { Square }\end{array}$ & F Value & Prob \\
\hline 1 & Replication & 2 & 0.181 & 0.090 & 0.1826 & \\
\hline 2 & Factor A & 1 & 1290.007 & 1290.007 & 2608.5351 & 0.0000 \\
\hline 4 & Factor B & 23 & 168.326 & 7.319 & 14.7989 & 0.0000 \\
\hline 6 & AB & 23 & 25.160 & 1.094 & 2.2120 & 0.0040 \\
\hline 7 & Error & 94 & 46.486 & 0.495 & & \\
\hline Total & Total & 143 & 1530.160 & & & \\
\hline
\end{tabular}

Coefficient of Variation: 2. 74\%. 
Table 6. Mean comparison of M. phaseolina pathogenecity on the different plants species

\begin{tabular}{|c|c|c|}
\hline No. of isolates & Disease index & $\alpha=0.01$ \\
\hline 5 & 27.00 & $\mathrm{~A}$ \\
\hline 2 & 27.00 & A \\
\hline 24 & 27.00 & $\mathrm{~A}$ \\
\hline 11 & 27.00 & A \\
\hline 23 & 27.00 & A \\
\hline 15 & 26.67 & $\mathrm{AB}$ \\
\hline 8 & 26.50 & $\mathrm{ABC}$ \\
\hline 1 & 26.50 & $\mathrm{ABC}$ \\
\hline 6 & 26.17 & ABCD \\
\hline 17 & 25.00 & BCDE \\
\hline 12 & 26.00 & $\mathrm{BCDE}$ \\
\hline 9 & 26.00 & $\mathrm{BCDE}$ \\
\hline 16 & 25.83 & $\mathrm{BCDEF}$ \\
\hline 22 & 25.67 & CDEFG \\
\hline 21 & 25.50 & DEFG \\
\hline 18 & 25.50 & DEFG \\
\hline 19 & 25.33 & DEFG \\
\hline 13 & 25.17 & EFG \\
\hline 20 & 25.00 & $\mathrm{FGH}$ \\
\hline 14 & 24.83 & $\mathrm{GHI}$ \\
\hline 3 & 24.17 & HIJ \\
\hline 4 & 24.00 & IJK \\
\hline 10 & 23.83 & $\mathrm{JK}$ \\
\hline 7 & 23.17 & $\mathrm{~K}$ \\
\hline
\end{tabular}

Table 7. Pathogenicity of 24 isolates of $M$. phaseolina on two plant species

\begin{tabular}{|l|c|c|}
\hline Species & Cutivars & Average of disease index \\
\hline Glycine max & willyams & $28.56 \mathrm{a}$ \\
\hline Helianthus annuus & Master & $22.48 \mathrm{~b}$ \\
\hline
\end{tabular}


Table 8. Mean comparison of interaction among different plants species and $M$. phaseolina isolates

\begin{tabular}{|c|c|c|c|c|c|}
\hline $\begin{array}{l}\text { Name of host } \\
\text { and NO. of } \\
\text { isolates }\end{array}$ & $\begin{array}{c}\text { Mean } \\
\text { diseases } \\
\text { index }\end{array}$ & $\alpha=0.01$ & $\begin{array}{l}\text { Name of host } \\
\text { and NO. of } \\
\text { isolates }\end{array}$ & $\begin{array}{c}\text { Mean } \\
\text { diseases } \\
\text { index }\end{array}$ & $\alpha=0.01$ \\
\hline $5 *$ soybean & 30 & A & $2 *$ sunflower & 24.67 & $\mathrm{~F}$ \\
\hline $23{ }^{*}$ soybean & 30 & $\bar{A}$ & $5 *$ sunflower & 24.00 & FG \\
\hline $24 *$ soybean & 30 & $\mathrm{~A}$ & $24 *$ sunflower & 24.00 & FG \\
\hline 11 *soybean & 30 & $\mathrm{~A}$ & 11 *sunflower & 24.00 & FG \\
\hline $15^{*}$ soybean & 29.67 & $\bar{A}$ & $23 *$ sunflower & 24.00 & FG \\
\hline 1 *soybean & 29.67 & $\mathrm{~A}$ & $8 *$ sunflower & 24.00 & FG \\
\hline $2 *$ soybean & 29.33 & $\overline{A B}$ & $15 *$ sunflower & 23.67 & FGH \\
\hline $6^{*}$ soybean & 29.33 & $\overline{\mathrm{AB}}$ & 17 * sunflower & 23.33 & $\mathrm{GH}$ \\
\hline $12 *$ soybean & 29.00 & $\mathrm{ABC}$ & 1 *sunflower & 23.33 & GH \\
\hline $8^{*}$ soybean & 29.00 & $\overline{\mathrm{ABC}}$ & $16 *$ sunflower & 23.00 & GHI \\
\hline $22 *$ soybean & 29.00 & $\overline{\mathrm{ABC}}$ & $12 *$ sunflower & 23.00 & GHI \\
\hline $9 *$ soybean & 29.00 & $\overline{\mathrm{ABC}}$ & $19 *$ sunflower & 23.00 & $\overline{\mathrm{GHI}}$ \\
\hline $17 *$ soybean & 28.67 & ABCD & $21 *$ sunflower & 23.00 & GHI \\
\hline $16^{*}$ soybean & 28.67 & $\mathrm{ABCD}$ & 9*sunflower & 23.00 & GHI \\
\hline $18^{*}$ soybean & 28.67 & $\mathrm{ABCD}$ & $6^{*}$ sunflower & 23.00 & GHI \\
\hline $21 *$ soybean & 28.00 & BCDE & $13 *$ sunflower & 22.67 & GHI \\
\hline $14^{*}$ soybean & 28.00 & $\mathrm{BCDE}$ & $22 *$ sunflower & 22.33 & $\mathrm{HI}$ \\
\hline $13^{*}$ soybean & 27.67 & $\mathrm{CDE}$ & $18 *$ sunflower & 22.33 & $\mathrm{HI}$ \\
\hline $20 *$ soybean & 27.67 & $\overline{\mathrm{CDE}}$ & $20 *$ sunflower & 22.33 & HI \\
\hline $4 *$ soybean & 27.67 & $\mathrm{CDE}$ & $14 *$ sunflower & 21.67 & I. \\
\hline $19 *$ soybean & 27.67 & $\mathrm{CDE}$ & $10 *$ sunflower & 20.67 & JK \\
\hline 3*soybean & 27.67 & $\mathrm{CDE}$ & $3^{*}$ sunflower & 20.67 & JK \\
\hline $7 *$ soybean & 27.33 & $\mathrm{DE}$ & $4 *$ sunflower & 20.33 & K \\
\hline $10^{*}$ soybean & 27.00 & $\mathrm{E}$ & $7 *$ sunflower & 19.00 & $\mathrm{~L}$ \\
\hline
\end{tabular}

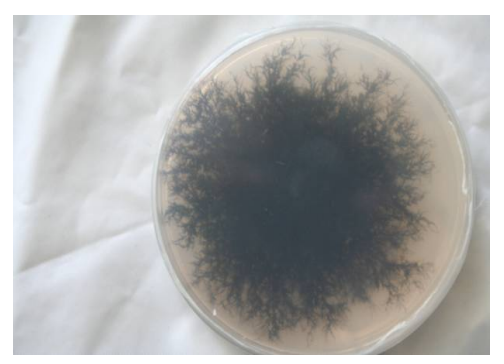

A

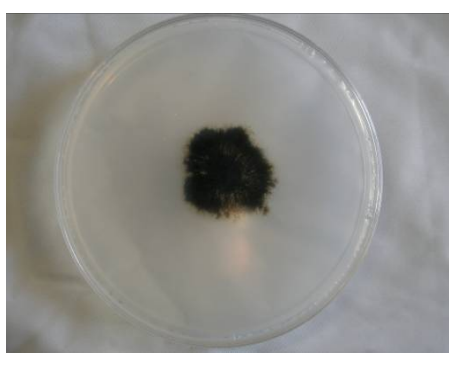

$\mathrm{B}$

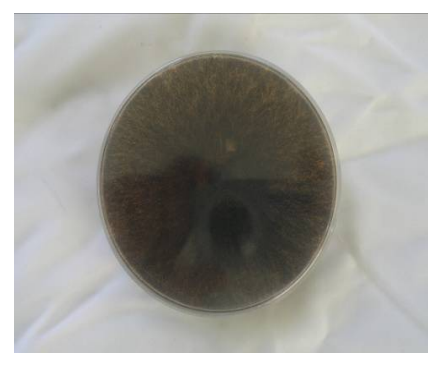

$\mathrm{C}$

Figure 1. Owth patterns of Macrophomina phaseolina on a minimal medium containing $120 \mathrm{mM}$ potassium chlorate. A, Feathery, B, restricted and C, dense 


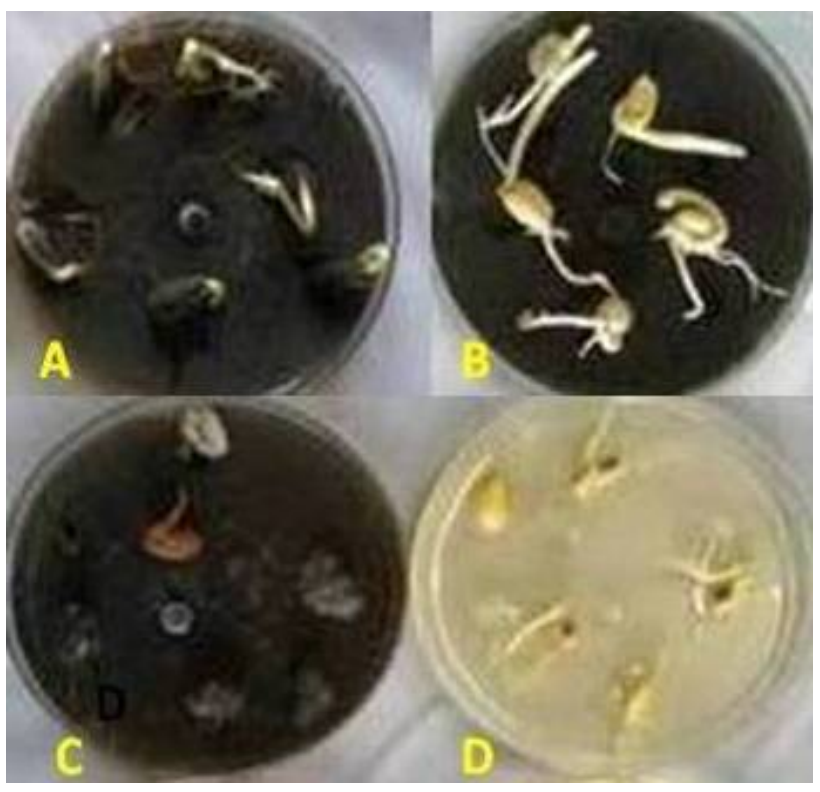

Figure 2. The pathogenicity test of M. phaseolina on sunflower (A), maize (B), soybean (C) and check (D) 